\title{
A Model for Improving Human Resource Performance in the Context of Knowledge Donating
}

\author{
Wuryanti Wuryanti® ${ }^{\bowtie}$ Indrianto Setiawan
}

Faculty of Economics, Islam Sultan Agung University, Semarang, Indonesia

\begin{tabular}{l} 
Info Article \\
\hline History Article: \\
Received July 2017 \\
Approved August 2017 \\
Published September 2017 \\
\hline Keywords: \\
Self-Efficacy; Social Competence; \\
Knowledge Donating; \\
Performance.
\end{tabular}

Received July 2017

Approved August 2017

Published September 2017

Self-Efficacy; Social Competence;

Performance.

\begin{abstract}
This study aims to examine the relationship between self efficacy, social competence and knowledge donating variables on organizational performance. This research uses quantitative research method by using primary data taken from questionnaires dispersion. The population of this study is all employees who work in KPP Pratama Semarang (Office Tax) consisting of 113 respondents. While the sampling is done through the census method. Analysis technique of this research using Moderating Regression Analysis (MRA) technique. The results of this study indicate that there is a significant influence of self efficacy and social competence on performance. Thus, to improve the performance of the tax office needs to improve self-efficacy of employees, especially their readiness to risk their jobs by giving them some skills to minimize risks on the job, such as technical skills, organizational skills and leadership skills. The tax office also needs to improve the social competence, especially the sense of concern for their employees. The tax office also needs to create conditions that support fellow employees in order to willing to share new knowledge.
\end{abstract}

Model Peningkatan Kinerja Sumber Daya Manusia dalam Konteks Sumbangan Pengetahuan

\begin{abstract}
Abstrak
Penelitian ini bertujuan untuk menguji hubungan antara variabel keyakinan diri, kompetensi sosial dan sumbangan pengetahuan terhadap kinerja organisasi. Penelitian ini menggunakan metode penelitian kuantitatif dengan menggunakan data primer yang diambil dari penyebaran kuestioner. Populasi penelitian ini adalah seluruh karyawan yang bekerja di KPP Pratama Semarang (Kantor Pajak) yang terdiri dari 113 responden. Sedangkan sampling dilakukan melalui metode sensus. Teknik analisis penelitian ini menggunakan teknik Moderating Regression Analysis (MRA). Hasil penelitian ini menunjukkan bahwa ada pengaruh yang signifikan dari self efficacy dan kompetensi sosial terhadap kinerja. dengan demikian, untuk meningkatkan kinerja kantor pajak perlu meningkatkan self-efficacy dari karyawan, terutama kesiapan mereka dalam mengambil risiko pekerjaan mereka dengan memberikan beberapa keterampilan kepada mereka untuk meminimalkan risiko pada pekerjaan, seperti keterampilan teknis, keterampilan organisasi dan keterampilan kepemimpinan. Kantor pajak juga perlu meningkatkan kompetensi sosial, terutama rasa kepedulian terhadap karyawan mereka. Kantor pajak juga perlu menciptakan kondisi yang mendukung sesama karyawan agar bersedia untuk berbagi pengetahuan baru.
\end{abstract}

JEL Classification: M2, M21

How to Cite: Wuryati, W \& Setiawan, I. 2017. A Model for Improving Human Resource Performance in the Context of Knowledge Donating. Jurnal Dinamika Manajemen. 8 (2): 208-215. 
Wuryanti Wuryanti \& Indrianto Setiawan / A Model for Improving Human Resource...

\section{INTRODUCTION}

Global competition requires every government institutions to be able to optimize and manage human resources. Human resources play important role in an organization because they always have active and dominant role in every activity of the organization. Every organization both engaged in the services and industry sector always seeks to manage human resource management in professional ways to improve performance. In order to improve performance, the presence of employees with social competence, self-efficacy and knowledge donating is needed.

Human resource is a very important factor in organization both in large and small scale. In large scale organizations, human resource is seen as a crucial element in the process of company development, the role of human resources is becoming increasingly important (Alharthey \& Rasli, 2012). The development of the business world will be realized if supported by qualified human resources.

The ideal function on the implementation of employees' duty in the work unit is a service function. Therefore, the employees of the government agencies should try their utmost to provide maximum services to anyone in need. If the services are not satisfactory, then, the agency can obtain a bad image of the community. Therefore, it is urgently needed the improvement of employee performance.

Employees and companies are the two things that cannot be separated. Employees play a major role in running the company's life. Employees who are satisfied with what they have got from the company will give more than what is expected and they will continue to try to improve their performance. Conversely, if the employees have lower work satisfaction, they tend to see the work as a dull and boring thing so that they will work in force and not serious (Ehrhart, 2006; Robbins, 2006) also said that someone with a high level of satisfaction will show a positive attitude towards work, whereas a person who is not satisfied with his work will show negative attitudes towards the job.
Therefore, the company should not ignore this because the employee satisfaction has a direct impact on the performance of employees which of course also affects the productivity of the company. in addition, for nearly 50 years, the psychologists in the field of industry and organizations have the same assumption that job satisfaction provides direct implications on the success of the organization.

Hauge et al. (2006) argue that the performance is the result of work produced by the employees or the real behavior that is displayed according to their role within the organization. Performance also means the results achieved by someone both quality and quantity in accordance with the responsibilities given to him. Additionally, someone's performance is influenced by the level of education, initiative, work experience and motivation. the results of one's work will provide feedback for the man himself to always actively do the work well and is expected to produce good quality work. Education affects a person's performance because it can provide wider insight to initiate and innovate and further affect the performance.

Employee performance is influenced by self-efficacy (Judge et al., 2007). Efficacy is a self-assessment, whether it can take good or bad action, right or wrong, capable of doing or not as required. Efficacy is different with the aspiration, because the ideals describe something that should be achieved (achievable), whereas the efficacy describes the self- assessment capability.

Social competence also affects the performance of employees, social competence is the ability to establish and maintain working relationships and interact with others in a social duty as an attempt to achieve personal goals and objectives of the organization. Social competence is based on employee's ability to maintain a cooperative relationship with other people (Judge et al., 2007; Putri \& Yuniawan, 2016).

Someone with a high level of satisfaction will show a positive attitude towards work, so that for the opposite. Therefore, the company should not ignore this because the employee satisfaction has a direct impact on the perfor- 
mance of employees which of course also affects the productivity of the company. in addition, for nearly 50 years, the psychologists in the field of industry and organizations have the same assumption that job satisfaction provides direct implications on the success of the organization.

The low social competence and self-efficacy of employees in the tax authorities leads to the performance decrease. As a result, the target assessed taxes will not be able to be fulfilled.

\section{Hypothesis Development Goal Setting Theory}

Goal setting theory suggests that people are committed to the goal. Such effect is related to the specificity of purpose, challenges and feedback on performance. In particular, it can be said that the establishment of specific goals can improve performance; a difficult goal, when received, results in higher performance than the easy ones; and the presence of feedback produces a higher performance than no feedback. Based on this view, then to determine specific and challenging goals for the employees is the best thing to do by managers to improve performance. When the level of goal commitment and self-efficacy is high, then the performance of employee is motivated on goal.

Furthermore, put forward the theory of self-efficacy (self-efficacy also known as social cognitive theory or social learning theory) refers to the belief that one is capable of doing a task. The higher self-efficacy is, the higher the confidence will be possessed as the ability to succeed in a task. Individual with a high self-efficacy will try harder to beat the challenge.

Social learning theory asserts that the result of experience and personal observations on the experience of others related to human development depends on: 1) the ability to perform the task successfully in a variety of types of behavior; and 2) the possibility to be achieved in a variety of behavior followed by the values that will be obtained from the results to be achieved. The first part of the expectancy associated with individual ability to behave in a successful performance is known as the efficacy expectation. The second part to do something with the perception of a good relationship between the behavior and the resulting destination is known as outcome expectation. The relationship between the components of social learning theory and expectancy theory is quite clear. Expectancy theory is driven directly by the effort toward performance. It shows a person's belief that he will be successful or demonstrate a good performance and be successful.

\section{Self-Efficacy}

Mallinckrodt and Wei (2005) states that self-efficacy is a person's beliefs about his ability to perform a behavior to succeed. The conviction of personal ability affects personal motivation, the higher the self-efficacy is, the lower the level of stress will be. Conversely, the higher the confidence of his own ability is, then the more robust the determination to complete the task well. Belief in the efficacy affects the level of challenge in completing the task. To perform various tasks, people who have high self-efficacy are those who perform very well. Those who have self-efficacy are happy to meet the challenge, while those who are doubtful; they do not even try, no matter how good their true abilities are. Self-confidence increases the desire to excel, while doubts are to pull it down.

The level of self-efficacy is a predictive tool which is more appropriate for someone's performance compared to the skills or training possessed before someone is employed (Judge et al., 2007). The level of self-efficacy is determined by previous experiences (successes and failures), the experience recognized by others (by observing the successes and failures of others), verbal persuasion (from friends, colleagues, relatives) and emotional state (fear). The perception that a person has ability to perform the duties will increase the likelihood of these tasks can be completed successfully.

Based on the explanation of self-efficacy, it can be expressed conceptually that self-efficacy is a person's belief in the ability to carry out the task as well as possible. The indicators of 
Wuryanti Wuryanti \& Indrianto Setiawan / A Model for Improving Human Resource...

self-efficacy are: feeling of being able to complete the task, take decisions and ready to accept the risk of job.

H1: Self efficacy has positive effect on employee performance

\section{Social Competence}

Jian and Wang (2013) stated that social competence is based on the ability to build cooperation with others. Levin et al. (2002) suggests that social competence leads to the employee's ability to interact with others in a social duty. Judge et al. (2007) suggests that social competence is based on an employee's ability to maintain a cooperative relationship with other people.

The social competence owned by employees is very important in improving employee performance. Social competence reflects the ability of employees to collaborate and interact with others in working to achieve personal goals and objectives of the organization. Low social competence is seen from a lack of the ability of employees to interact with the public, so that employees are less able to convince and influence society. Indicators of social competence are: Being empathy, having extensive networks, maintaining relationships built and having a formal work contacts.

$\mathrm{H} 2$ : Social competence has positive effect on employee performance

\section{Knowledge Donating}

Knowledge Donating as a new perspective to learning process of an organization is one of the median that allows the members of a group, organization, institution or companies to share science, technique, experience and ideas they have to other members by not forgetting the means of access for companies to gain such knowledge through the support of technology and innovation as well as strategic management (Ipe, 2003; Tobing, 2007; Pasaribu, 2009; Elianto \& Wulansari, 2016).

According to Chen et al. (2006) and Arizqi (2017), knowledge donating has already included the notion of knowledge transfer which is defined as a systematic process of transmitting, distributing and disseminating knowledge and multidimensional context of a person or organization to the person or organization in need through varied methods and media. This process is aimed to optimize the use or exploit the existing knowledge and to encourage the creation of new knowledge as a result of the learning and the combination of different knowledge.

Prior to improve its performance, an organization has to go through a learning process of knowledge Donating a new perspective to the learning process of an organization as one of the median that allows the members of a group, organization, institution or company to share science, technique, experience and ideas they have to other members by not forgetting the means of access for companies to gain such knowledge through the support of technology and innovation as well as strategic management (Ipe, 2003; Pasaribu, 2009; Tobing, 2007; Dysvik et al., 2015).

According to Hsu and Wang (2008), the ability to assimilate knowledge related to knowledge that is newly accepted is to enable them to understand and absorb the new knowledge obtained. Another capability is to increase the absorptive capacity of knowledge through media and proactively provide information and experience to others that are relevant to the field of competence experienced by employees. The indicators of knowledge donating are: sharing new knowledge, sharing new information about the work, having attention to co-workers and sharing a story about work.

H3: Knowledge Donating moderates the effect of self-efficacy on employee performance

H4: Knowledge Donating moderates the effect of social competence on employee performance

\section{METHOD}

This was a quantitative study using primary data taken from distributing questinnaire whose data tabulation was analyzed through 
Moderating Regression Analysis by MRA analysis technique. Then, the result of the test was interpreted into result analysis. Population determined in this study was all employees worked in KPP Pratama Semarang consisting of 113 respondents. While the sampling was conducted through census method, which means that the sample is as many as the population.

Variables in this study were social competence, self-efficacy, knowledge donating and employee performance with following definitions: Social competence is an ability to build and maintain cooperative relationship and interact with other in term of conducting social tasks as an effort to achieve both personal and organizational goals. The indicators used were empathy feeling, wide networking, maintaining relationship, having work contact. Knowledge donating refers to a process where individuals share their knowledge one to each other. The indicators used were sharing new knowledge, sharing work information, caring to co-workers, sharing story about work.

Self-efficacy deals with a capacity to get result or effect desired, while the term self refers to someone referred. The indicators used were being able to finshing tasks, being able to take decision, willing to take risks of work. Employee performance is a result achieved by emplyees in their work according to certain criteria applied in a certain work. The indicators used were quality, quantity, knowledge and punctuality.

The analysis used to answer the Hypothesis was conducted by statistical computation and SPSS program to test the Hypothesis determined whether or not they are approved. In this study, the statistical computation was conducted by using Moderating Regression Analysis (MRA) model.

\section{RESULTS AND DISCUSSION}

\section{Hypothesis Test without Moderation}

To test the Hypothesis by using $\mathrm{t}$-test and f-test, it needs to conduct regression analysis. The analysis was used in this study to find out whether or not there was an effect of independent variable (Ghozali, 2011) i.e. self-efficacy and social competence toward employee performance. Statistical computation on multiple linear regression analysis used in this study was conducted through SPSS for Windows 22.5. While the summary of data analysis by using the software is as Table 1. From Table 1 multiple linear regression analysis can be formulated as follow:

Employee Performance $=0.614 \mathrm{ED}+0.445 \mathrm{KS}$

Table 1. Coefficients

\begin{tabular}{llccc}
\hline \multicolumn{1}{c}{ Model Beta } & Standardized Coefficients & T & Sig. \\
\hline 1 & (Constant) & & 4.982 & 0.000 \\
& Self-efficacy (ED) & 0.614 & 2.665 & 0.009 \\
& Social Competence (KS) & 0.445 & 2.298 & 0.028 \\
\hline
\end{tabular}

Table 2. Coefficients

\begin{tabular}{llccc}
\hline \multicolumn{1}{c}{ Model } & Standardized Coefficients & T & Sig. \\
\cline { 3 - 5 } & \multicolumn{1}{c}{ Beta } & & \\
\hline 1 & $\begin{array}{l}\text { (Constant) } \\
\text { Self-efficacy (ED) x Knowledge Donat- } \\
\text { ing (KD) }\end{array}$ & 0.156 & 2.009 & 0.000 \\
$\quad \begin{array}{l}\text { Social Competence (KS) x Knowledge } \\
\text { Donating (KD) }\end{array}$ & 0.286 & 2.127 & 0.049 \\
\hline
\end{tabular}


Wuryanti Wuryanti \& Indrianto Setiawan / A Model for Improving Human Resource...

Table 3. R-Square

\begin{tabular}{cccc}
\hline Model & Adjusted R Square & Std. Error of the Estimate & Durbin-Watson \\
\hline 1 & 0.573 & 0.41471 & 2.142 \\
\hline
\end{tabular}

\section{Hypothesis Test with Moderation}

Statistical computation on the analysis of moderating regression analysis (MRA) used in this study were assisted SPSS for Windows 22.5. While the summary result of data analysis using the program is as Table 2 and Table 3.

$$
\begin{aligned}
\text { Employee Performance }= & 0.156 \mathrm{ED} \times \mathrm{KD}+ \\
& 0.286 \mathrm{KS} \times \mathrm{KD}
\end{aligned}
$$

The coefficient of determination is an indicator for the height of independent variables' effect on dependent variables. The coefficient value was shown from adjusted $\mathrm{R} 2$ value. The finding of this study resulted that adjusted $\mathrm{R} 2$ valued 0.573 (Table 3). This indicates that $57.3 \%$ of employee performance could be determined by self-efficacy and social competence, while the rest $42.7 \%$ of employee performance was affected by other variables which were not included in this model. This indicates that employee performance is not only affected by self-efficacy and social competence, but also other variables.

The partial test on self-efficacy variable resulted regression coefficient 0.614 with siginificance 0.009 . The significant value which is lower than 0.05 shows that self-efficacy variable gave significant effect on employee performance. The regression coefficient was in positive direction showing that there was positive effect of selfefficacy on employee performance. This indicates that employees with high self-conficence are able to improve their performance. This finding is in line with the study which was conducted by (Mallinckrodt \& Wei, 2005).

The partial test on social competence variable resulted regression coefficient 0.445 with significance 0.028 . The significant value which is lower than 0.05 shows that social competence variable gave significant effect on employee performance. The regression coefficient was in po- sitive direction showing that there was positive effect of social competence on employee performance. This indicates that employees with high social competence are able to improve their performance. This finding is in line with the study which was conducted by (Judge et al., 2007).

The test on the role of knowledge donating in moderating the effect of self-efficacy on employee performance resulted regression coefficient 0.156 with significance 0.049 . The significant value which is lower than 0.05 shows that knowledge donating variable was able to moderate the effect of self-efficacy on employee performance. The regression coefficient was in positive direction showing that there was positive role of knowledge donating toward employee performance.

This indicates that employees with good knowledge donating are able to improve their self-confidence in improving their performance. This finding is in line with the study which was conducted by (Endres et al., 2007; Goh \& Sandhu, 2014; Al-Husseini \& Elbeltagi, 2014). The test on the role of knowledge donating in moderating the effect of social competence on employee performance resulted regression coefficient 0.286 with significance 0.034 . The significant value which is lower than 0.05 shows that knowledge donating was able to moderate the effect of social competence on employee performance.

The regression coefficient was in positive direction showing that there was positive role of knowledge donating in moderating the effect of social competence on employee performance. This indicates that employees with good knowledge donating are able to improve their social competence in improving their performance. This finding is in line with the study which was conducted by (Levin et al., 2002; Sutton \& Melanie, 2006). 


\section{CONCLUSIONAND RECOMMENDATION}

Based on the findings in this study, it can be concluded that the higher self-efficacy, the higher employee performance, which means that employee performance is developed by the indicators of self-efficacy including feelings of being able to finish tasks, taking decision and readiness in taking risks of work.

The higher social competence, the higher employee performance, which means that employee performance is developed by the indicators of social competence including empathy, wide network and built relationship maintenance. High knowledge donating enables self-efficacy to improve employee performance, meaning that employee performance is developed by the indicators of knowledge donating including sharing new knowledge and new information about work, caring with co-workers and sharing story about work. High knowledge donating enable social competence to improve employee performance, which means that employee performance is developed by the indicators of knowledge donating including sharing new knowledge and new information about work, caring with coworkers and sharing story about work.

KPP Pratama Semarang needs to improve self-efficacy of the employees, mainly their readiness in taking risks of their work through giving several skills to them in order to minimize risks on work, such as technical skill, organization skill and leadership skill. KPP Pratama Semarang also needs to improve social competence, mainly emphaty feeling of their employees and therefore, KPP Pratama Semarang needs to have gathering intensively or outbound activities or ESQ training for the employees in order that communication and hospitality can be more created among them.

KPP Pratama Semarang should improve knowledge donating, mainly in order that the employees are willing to share new knowledge. One of the affordable efforts is brainstorming activities. By implementing brainstrorming, sharing of ideas among them can be done. KPP
Pratama Semarang needs to improve human resource performance mainly the quality of the employee. This can be done through training for them, giving chance for them to have further study and holding seminar or symposium.

The limitation in this study which can be inferred is as follow: limitation on modelling of this study that the variables are still low in determining employee performance on KPP Pratama Semarang, which can be shown from coefficent value of determination that is relatively low. The findings of this study and some limitations found in this study can be sourceful ideas to develop this study in the future.

Therefore, some points of extensive study suggested from this study are: Adding independent variables which affect employee performance. The suggested variables are: intrinsict motivation, this is because it needs high selfconfidence of employees in giving service to public to improve applicants' trust on the service of KPP Pratama Semarang, with high intirisict motivation employees are able to finish applicants' problem well. During the process of questionnaire distribution, it is suggested that each respondent should be directly met in order that the respondents are able to understand questions given in the questionnaire.

\section{REFERENCES}

Alharthey, B. K \& Rasli, A. 2012. The Use of Human Resource Management Systems in the Saudi Market. Asian Journal of Business Ethics. 1 (2): 163-176.

Al-Husseini, S \& Elbeltagi, I. 2014. Knowledge Sharing Practices as a Basis of Product Innovation: a Case of Higher Education in Iraq. International Journal of Social Science and Humanity. 5 (2): 182-185

Arizqi, A. 2017. Performance Enhancement Model of Human Resources through Knowledge Sharing. Jurnal Dinamika Manajemen. 8 (1): 134-142

Chen, S., Duan, Y., Edwards, J. S \& Lehaney, B. 2006. Toward Understanding Inter-organizational Knowledge Transfer Needs in SMEs: Insight 
Wuryanti Wuryanti \& Indrianto Setiawan / A Model for Improving Human Resource...

from a UK Investigation. Journal of Knowledge Management. 10 (3): 6-23.

Dysvik, A., Buch, R \& Kuvaas, B. 2015. Knowledge Donating and Knowledge Collecting. Leadership \& Organization Development Journal. 36 (1): $35-53$

Ehrhart, K. H. 2006. Job Characteristic Beliefs and Personality as Antecedents of Subjective Person-Job Fit. Journal of Business and Psychology. 21 (2): 193-226.

Elianto, W \& Wulansari, N. A. 2016. Building Knowledge Sharing Intention with Interpersonal Trust as a Mediating Variable. Jurnal Manajemen Teknologi. 15 (1): 67-76.

Endres, M. L., Endres, S. P., Chowdhury, S. K \& Alam, I. 2007. Tacit Knowledge Sharing, SelfEfficacy Theory and Application to the Open Source Community. Journal of Knowledge Management. 11 (3): 92-103.

Ghozali, I. 2011. Aplikasi Analisis Multivariate dengan Program SPSS. Semarang: Badan Penerbit Universitas Diponegoro.

Goh, S. K \& Sandhu, M. S. 2014. The Influence of Trust on Knowledge Donating and Collecting: an Examination of Malaysian Universities. International Education Studies. 7 (2): 125-136.

Hauge, J. B., Imtiaz, A., Auerbach, M., Eschenbacher, J \& Seifert, M. 2006. Enhancements in Performance Through Virtual Collaboration among SMEs Potentials, Needs and Research Challenges. In Working Conference on Virtual Enterprises. Springer, Boston, MA: 255-264.

Hsu, I. C \& Wang, Y. S. 2008. A Model of Intraorganizational Knowledge Sharing: Development and Initial Test. Journal of Global Information Management. 16 (3): 45-73.

Ipe, M. 2003. Knowledge Sharing in Organizations: a Conceptual Framework. Human Resource Development Review. 2 (4): 337-259.

Jian, Z \& Wang, C. 2013. The Impacts of Network Competence, Knowledge Sharing on Service Innovation Performance: Moderating Role of Relationship Quality. Journal of Industrial Engineering and Management. 6 (1):25-49.

Judge, T. A., Jackson, C. L., Shaw, J. C., Scott, B. A \& Rich, B. L. 2007. Self-Efficacy and WorkRelated Performance: the Integral Role of Individual Differences. Journal of Applied Psychology. 92 (1): 107-127.
Kang, J. W \& Heshmati, A. 2008. Effect of Credit Guarantee Policy on Survival and Performance of SMEs in Republic of Korea. Small Business Economics. 31 (4): 445-462.

Levin, D. Z., Cross, R., Abrams, L. C \& Lesser, E. L. 2002. IBM Institute for Knowledge-Based Organizations Trust and Knowledge Sharing: a Critical Combination Trust is Critical. IBM Institute for Knowledge Based Organizations. 19.

Mallinckrodt, B \& Wei, M. 2005. Attachment, Social Competencies, Social Support and Psychological Distress. Journal of Counseling Psychology. 52 (3): 358-367.

Millán, J. M., Hessels, J., Thurik, R \& Aguado, R. 2013. Determinants of Job Satisfaction: a European Comparison of Self-Employed and Paid Employees. Small Business Economics. 40 (3): 651-670.

Ngah, R \& Jusoff, K. 2009. Tacit Knowledge Sharing and SMEs' Organizational Performance. International Journal of Economics and Finance. 1 (1): 216-220.

Pasaribu, M. 2009. Knowledge Sharing. Meningkatkan Kinerja Layanan Perusahaan. Jakarta: PT. Elex Media Computindo.

Peraturan Pemerintah Republik Indonesia Nomor 10 tahun 1979 tentang Penilaian Pelaksanaan Pekerjaan Pegawai Negeri Sipil.

Peraturan Pemerintah Republik Indonesia Nomor 46 tahun 2011 tentang Penilaian Prestasi Kerja Pegawai Negeri Sipil.

Putri, V. W \& Yuniawan, A. 2016. Organizational Effectiveness: Social Capital and Competitive Advantage Approach. Jurnal Dinamika Manajemen. 7 (1): 76-90.

Tabasi, M. M., Vaezi, R \& Alvani, S. M. 2014. Relationship between Strategic Human Resource Management Practices and Organizational Innovation with Respect to the Role of Organizational Learning. Kuwait Chapter of Arabian Journal of Business and Management Review. 3 (7): 170-185.

Sutton, M \& Melanie. 2006. Emotional Intelligence and Competence in a Knowledge Citizen's World. SA Journal of Information Management, 8 (4).

Tobing, L. P. 2007. Knowledge Management. Konsep, Artitektur dan Implementasi. Yogyakarta: Graha Ilmu. 